\title{
Production and cash flow of oil palm intercropping systems an amazonian degraded area
}

\author{
Raimundo Nonato Carvalho ROCHA ${ }^{*}$, Maria do Rosário Lobato RODRIGUES², \\ Ricardo LOPES 2 , Alex Queiroz CYSNE², Jeferson Luiz Vasconcelos de MACEDO² \\ ${ }^{1}$ Empresa Brasileira de Pesquisa Agropecuária, Embrapa Pesca e Aquicultura, Palmas, Tocantins, Brasil. \\ ${ }^{2}$ Empresa Brasileira de Pesquisa Agropecuária, Embrapa Amazônia Ocidental, Manaus, Amazônia, Brasil. \\ (ORCID: 0000-0003-3617-5112; 0000-0002-5559-9685; 0000-0003-3943-4159; 0000-0002-5327-2128) \\ *E-mail: raimundo.rocha@embrapa.br (ORCID: 0000-0003-3093-6144)
}

Recebido em: 18/03/2019; Aceito em: 27/09/2019; Publicado em: 04/02/2020.

\begin{abstract}
The objective of this study was to analyze the technical viability and cash flow of intercrop cultivation in the first three years after oil palm planting in a degraded area of the Amazon. Four intercropping systems were tested: SI - oil palm + banana; SII - oil palm + cassava; SIII - oil palm + pineapple, and SIV - oil palm in monoculture. Intercropping was performed during the first three years of oil palm planting and the cash flow of the systems evaluated during this period. The oil palm bunches production was evaluated from 7 th to 10 th year after planting. SIII had best financial performance, with deployment and maintenance costs $100 \%$ amortized over the three years of the system. The SI and SII systems amortized $86.7 \%$ and $64.5 \%$ of the costs, respectively. Oil palm bunches production was not affected by intercropping. Yield of intercrops was similar to that expected from the crops in monoculture. The intercropping systems evaluated provide a technically and economically viable alternative to generate income and amortize planting and maintenance costs during oil palm juvenile phase in degraded areas of the Amazon.
\end{abstract}

Palavras-chave: costs; Elaeis guineensis; integrated production.

Produção e fluxo de caixa de dendezeiro com culturas intercalares em área degradada na Amazônia

\begin{abstract}
RESUMO: O objetivo deste estudo foi analisar a viabilidade técnica e o fluxo de caixa do cultivo de culturas intercalares nos três primeiros anos após o plantio do dendezeiro em área degradada da Amazônia. Foram testados quatro sistemas de cultivo: SI - dendezeiro + banana; SII - dendezeiro + mandioca; SIII - dendezeiro + abacaxi e SIV - dendezeiro em monocultivo. O cultivo intercalar foi realizado durante os três primeiros anos de cultivo do dendezeiro e o desempenho financeiro dos sistemas avaliado pelo fluxo de caixa neste período. Para verificar a influência das culturas intercalares na produção do dendezeiro na fase adulta foi avaliada a produção de cachos do dendezeiro do $7^{\circ}$ ao $10^{\circ}$ ano após o plantio. O SIII apresentou melhor desempenho financeiro, com os custos de implantação e manutenção $100 \%$ amortizados nos três anos do sistema. Os sistemas SI e SII amortizaram 86,7\% e 64,5\% dos custos, respectivamente. A produção do dendezeiro não foi afetada pelos cultivos intercalares. A produtividade dos cultivos intercalares foi similar à esperada no monocultivo das espécies. Os cultivos intercalares testados são uma alternativa técnica e economicamente viável para gerar renda e amortizar os custos de implantação e condução do dendezeiro na fase jovem da cultura em áreas degradadas da Amazônia.
\end{abstract}

Keywords: custos; Elaeis guineensis; produção integrada.

\section{INTRODUCTION}

Oil palm (Elaeis guineensis Jacq.) is responsible for most of the vegetable oil produced in the world, around $38.2 \%$ in the 2016/17 crop, followed by soybeans, which in the same period accounted for $29.2 \%$ of production (UNITED STATES DEPARTMENT OF AGRICULTURE - USDA, 2017).

The worldwide consumption of vegetable oil is increasing and is expected to reach 240 million tons by 2050 (CORLEY, 2009). This growth in consumption will also be accompanied by an expansion of oil palm cultivation, especially in the humid tropics, a climate to which the species is very well adapted.
In Brazil such expansion must occur on areas that have already been deforested, as provided in the Law Project 7.326/2010, and under the Programa de Produção Sustentável da Palma de Óleo (Oil Palm Sustainable Production Program). Agroecological Zoning for oil palm cultivation in deforested areas of the Legal Amazon identified more than 30 million hectares of deforested areas suitable for oil palm cultivation (RAMALHO FILHO et al., 2010).

Commercial production of oil palm bunches begins at the end of the third/beginning of the fourth year after planting. In this unproductive period of approximately three years, a large investment of resources occurs with no immediate fiscal recompense. This is one of the main obstacles to the 
expansion of the crop, especially for family farmers (LIMA et al., 2002).

An option for income generation in the juveline phase (unproductive) of oil palm, is to grow annual or semiperennial plants between rows of palms, which also allows for more efficient exploitation of environmental resources such as soil, space, sunlight and $\mathrm{CO}_{2}$ (NCHANJI et al., 2016; AYNEHBAND et al., 2010; REZIG et al., 2010; ABERA; FEYISA, 2009).

In Malaysia, Ismail et al. (2009) cultivated banana, pineapple, peanut and soybean between rows in the oil palm unproductive phase and showed this to be technically and financially viabile in all studied options. In Brazil, Alves et al. (2015) studying oil palm intercropping systems in Roraima, reported different economic performances, depending on the crop arrangements and cultivation locations.

The current study analyzed the technical viability and cash flow of intercropping systems in the first three years after oil palm planting in a degraded area in Central Amazonia.

\section{MATERIALS AND METHODS}

The study was conducted at the Suframa Agricultural Distict Experimental Station/Embrapa Western Amazon, located at km-54 on theBR-174 ( $\left.2^{\circ} 31^{\prime} \mathrm{S}, 60^{\circ} 01^{\prime} \mathrm{W}\right)$, altitude 102 meters. The local climate is hot and humid, with average temperatures from $25-28^{\circ} \mathrm{C}$ and annual rainfall between 2,000 and $2,800 \mathrm{~mm}$. The annual relative humidity is high (between 85 and 90\%), and luminosity ranges from 1,500 to 3,000 hours/year of solar radiation.

According to the results of the analysis performed before the experiment was installed local soil is a Yellow Latosol with very clayey texture, low available nutrient content and high aluminum saturation (Table 1). The $\mathrm{pH}$ was measured in water (ratio 1:2.5), the nutrients $\mathrm{P}, \mathrm{Na}, \mathrm{K}, \mathrm{Fe}, \mathrm{Zn}, \mathrm{Mn}, \mathrm{Cu}$ were extracted by the Mehlich-1 method, $\mathrm{Ca}$ and $\mathrm{Mg}$ were extracted by the $\mathrm{KCl} 1 \mathrm{~mol} \mathrm{~L}^{-1}$ method and $\mathrm{H}+\mathrm{Al}^{+}$by Calcium Acetate extractor $0.5 \mathrm{~mol} \mathrm{~L}^{-1}$ ( $\mathrm{pH}$ 7.0). Particle size analyzes were based on the pipette method and the textural classification and performed following Santos et al. (2013).

The experimental area was covered by native forest until 1977, when forest removal occurred and Brachiaria bumidicola pasture was established for cattle raising. In 1986, the animals were removed and the area abandoned to natural regeneration. Prior to the preparation of the area for the experiment in 2003, the area was covered with capoeira-type vegetation, with low green biomassmass production, consisting mainly of herbaceous species (Borreria verticillata and Rolandra fruticiosa), shrubs and trees from the genera Vismia, Solanum, Anona and Laetia. Preparation of the experimental area was occurred between January to February 2004 , with the clearing and of the cover vegetation, and the removal and harrowing of the area.

Tabela 1. Características químicas e físicas do solo da área, antes da implantação do experimento, obtidas por amostragem da camada de 0 a 20 centímetros de profundidade.

Table 1. Chemical and physical characteristics of the soil of the area, prior to experiment initiation, obtained by sampling the layer from 0 to 20 centimeters in depth.

\begin{tabular}{|c|c|c|c|c|c|c|c|c|c|}
\hline \multicolumn{10}{|c|}{ Chemical analysis } \\
\hline $\mathrm{pH} \mathrm{H} \mathrm{H}_{2} \mathrm{O}$ & $\mathrm{C}$ & M.O. & $\mathrm{N}$ & $\mathrm{P}$ & $\mathrm{K}$ & $\mathrm{Ca}$ & $\mathrm{Mg}$ & $\mathrm{Al}$ & $\mathrm{H}+\mathrm{Al}$ \\
\hline 4.2 & 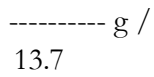 & 23.7 & $\begin{array}{l}(\%) \\
1.32\end{array}$ & 1.00 & 13.80 & 0.21 & $\begin{array}{c}\mathrm{cmol}_{\mathrm{c}} / \mathrm{d} \\
0.07\end{array}$ & 0.83 & 5.59 \\
\hline \multicolumn{10}{|c|}{ Physical analysis } \\
\hline Course sand & Fine sand & Total sand & Silt & & Clay & \multicolumn{4}{|c|}{ Texture classification } \\
\hline 104.8 & 29.1 & $\begin{array}{c}-g / \mathrm{kg}----- \\
134.0\end{array}$ & 180.0 & & 686.0 & \multicolumn{4}{|c|}{ Very clayey } \\
\hline
\end{tabular}

Soil acidity was corrected with application of $1.5 \mathrm{tha}^{-1}$ of dolomitic limestone. The Oil palm seedlings were planted in June 2004, with a spacing of $9 \mathrm{~m} \times 9 \mathrm{~m}$ in an equilateral triangle (143 plants ha $\left.{ }^{-1}\right)$. Between oil palm rows $(7.8 \mathrm{~m})$ was alternated an inter-row where espontaneous vegetation that had covered the soil before the preparation of the area for planting was piled, and other used for intercrops cultive. The intercrops were cultived keeping $1.5 \mathrm{~m}$ away from oil palm rows, occupying area of $4.8 \mathrm{~m}$ wide in inter-rows.

The experiment was established in a randomized block using a factorial scheme, with four intercropping systems, with and without liming, and three replications. Each oil palm plot contained 48 plants (eight rows of six plants), being four inter-rows of the plot used for intercropping. The intercropping treatments consisted of: System I - Two rows of the banana cultivar Thap Maeo were planted in each of the four oil palm inter-rows, with $2.5 \mathrm{~m}$ spacing between plants and $3.0 \mathrm{~m}$ between rows. Each plot consisted of 168 plants, occupying $37 \%$ of the total plot area (a density of 494 banana plants $\left.\mathrm{ha}^{-1}\right)$. Subsequent management followed the recommendations for northern region banana cultivation of GASPAROTTO; PEREIRA (2010). Harvesting occurred at 11, 16 and 23 months after planting. Immediately after harvesting, the bunch fresh weight was obtained, then the hand of the each bunch was removed and weighed, thus giving the weight of hands. System II - Three successive cultivation cycles of five rows of cassava, cultivar Aipim Manteiga, planted in each of the four rows of oil palm with a $1.0 \mathrm{~m} \times 1.0 \mathrm{~m}$ spacing. Each plot consisted of 1080 plants (a density of 3,200 cassava plants ha ${ }^{-1}$ ), occupying $32 \%$ of plot total area. Crop management followed cassava cultivation recommendations for the State of Amazonas (DIAS et al., 2003). Harvesting occurred eight months after planting. Yield was assayed using fresh weight of harvested roots. System III - Four double rows of a traditional pineapple variety used by farmers in the region in $1.0 \mathrm{~m}$ spacing between double rows with $0.4 \mathrm{~m}$ between row and $0.4 \mathrm{~m}$ between plants in a row. Each pineapple plot consisted of 1,928 plants (a density of 12,850 pineapple plants $\mathrm{ha}^{-1}$ ) occupying $36 \%$ of the total plot area. Crop management followed the recommendations for pineapple cultivation in the State of Amazonas (SILVA et al., 2004). Fruit harvesting began 15 months after planting and ended 18 months after planting. Number and weight of fresh fruit were evaluated. Fruits were classified into three categories: prime (weight $>1.5 \mathrm{~kg}$ ), second (weight $1.5-1.0 \mathrm{~kg}$ ) and third (weight $<1.0 \mathrm{~kg}$ ). System IV - Oil palm 
monoculture in conventional system, using cultivar BRS C2501, with between rows weed control by mechanical mowing. Crop management followed recommendations for oil palm cultivation in the Amazon (VIÉGAS; MULLER, 2000). Cluster production was recorded in the adult phase, from the 7 th to the 10th year after planting. Harvesting occurred every 15 days across the 48 study months. Bunch production was expressed in $\mathrm{kg} \mathrm{ha}^{-1} \mathrm{year}^{-1}$ of fresh fruit bunches (FFB), total number of bunches (NB), in units ha ${ }^{-1}$ year ${ }^{-1}$ and mean bunch weight (BW), obtained by FFB/NB ratio, in kilos.

For cash flow analysis of the four cultivation systems, production cost and the revenue from the sale of production were considered. Cash flow, the object of analysis, is represented by the net nominal revenue that results from the subtraction of the inputs (revenues) from the outputs (costs) (SANTANA, 2005).

Cost calculations included manual operations (crop planting, management and harvesting), mechanized operations (area clearing), inputs (organic and chemical fertilizer, limestone, seeds, seedlings and pesticides), equipments and tools. Human labor costs were calculated considering a daily remuneration of $\mathrm{R} \$ 20.00$ for the first and second year, and $\mathrm{R} \$ 30.00$ for the third year of the experiment. For inputs, equipment and tools, average prices in the Manaus market from 2004 to 2006 were considered.

To calculate revenues, prices paid to producers in the Manaus market at harvest time were used: $\mathrm{R} \$ 0.50 / \mathrm{kg}$ of bananas in the 1st, 2nd and 3rd cycle; pineapples $\mathrm{R} \$$ 1.20 /unit for prime-quality, $\mathrm{R} \$ 0.80 /$ unit for 2 nd and $\mathrm{R} \$$ root for 1 st crop, $\mathrm{R} \$ 0.30$ for the 2 nd crop and $\mathrm{R} \$ 0.40$ for the 3 rd crop.

\section{RESULTS}

Oil palm bunch production in adult phase, evaluated from the 7 th to the 10 th year after planting, did not differ statistically between the four cropping systems for any of the three evaluated variables (Table 2), FFB, NB and BW, indicating that the cultivation of the intercropped species did not influence oil palm productive performance.

Liming at the time of tillage also had no significant effect on the variables of oil palm cluster production during the evaluation period. The average annual yield of oil palm clusters was approximately $21 \mathrm{t} \mathrm{ha}^{-1}$ in all four forms (Table 3).

Intercropped banana plantation yields were $7,980 \mathrm{~kg} \mathrm{ha}^{-1}$, equivalent to $21,568 \mathrm{~kg} \mathrm{ha}^{-1}$ under monoculture. For cassava roots, mean intercrop yields across three cultivation cycles was $6,370 \mathrm{~kg} \mathrm{ha}$, equivalent to $19,906 \mathrm{~kg} \mathrm{ha}^{-1}$ under monoculture. For pineapple 11,732 fruits were harvested per intercropped ha, equivalent to 32,589 fruits $\mathrm{ha}^{-1}$ under monoculture.

The cost per hectare, considering planting and maintenance during the first three years of system cultivation, ranged from $\mathrm{R} \$ 12,729.45$ to $\mathrm{R} \$ 9,418.74$ between intercropped systems, and $\mathrm{R} \$ 7,016.28$ for oil palm monoculture (Table 4). Considering human labor used for area preparation, seedling planting, post-implantation management and harvesting, this component represented the majority of the costs in the evaluated systems, ranging from $37 \%$ for oil palm monoculture to $48 \%$ in oil palm + banana system.

Tabela 2. Resumo da análise de variância do peso total de cachos de frutos frescos (PTC), número total de cachos (NTC) e peso médio de cachos (PMC) de dendezeiro, avaliado do $7^{\circ}$ ao $10^{\circ}$ ano após o plantio, em quatro sistemas de cultivo (monocultura e consórcios nos três primeiros anos após o plantio com banana, macaxeira e abacaxi), com e sem calagem.

Table 2. Summary of variance analysis of total weight fresh fruits bunch (FFB), total number of bunches (NB) and mean bunch weight (BW) for oil palm, assasyed across 7-10 years after planting, in four cropping systems (monoculture and intercropping in the first three years after planting with banana, cassava and pineapple), with and without liming.

\begin{tabular}{|c|c|c|c|c|c|c|c|}
\hline \multirow{2}{*}{ FV } & \multirow{2}{*}{ DF } & \multicolumn{2}{|c|}{ FFB (PTC) } & \multicolumn{2}{|c|}{ NB (NTC) } & \multicolumn{2}{|c|}{ BW (PMC) } \\
\hline & & QM & $\mathrm{F}$ & QM & $\mathrm{F}$ & QM & $\mathrm{F}$ \\
\hline System (Sys) & 3 & 896946 & $0.04^{\mathrm{ns}}$ & 20477 & $0.265^{\text {ns }}$ & 1.12 & $0.84^{\mathrm{ns}}$ \\
\hline Liming (Lim) & 1 & 1215765 & $0.05^{\mathrm{ns}}$ & 18721 & $0.242^{\mathrm{ns}}$ & 0.18 & $0.14^{\mathrm{ns}}$ \\
\hline Sys*Lim & 3 & 1221087 & $0.53^{\mathrm{ns}}$ & 61956 & $0.801^{\mathrm{ns}}$ & 0.86 & $0.65^{\mathrm{ns}}$ \\
\hline Residual & 16 & 2305940 & & 77331 & & 1.32 & \\
\hline CV (\%) & & 22.9 & & 13.7 & & 11.2 & \\
\hline
\end{tabular}

Tabela 3. Produtividade de cachos de frutos frescos (PTC) do dendezeiro e das culturas intercalares, frutos de abacaxi, cachos de banana e raízes de mandioca, cultivadas nas entrelinhas nos três primeiros anos após o plantio do dendezeiro.

Table 3. Fresh fruit bunch (FFB) yield of oil palm and intercropping crops, pineapple fruits, banana hands and cassava roots, grown between the oil palm.rows in the first three years after planting

\begin{tabular}{|c|c|c|c|c|}
\hline \multirow{2}{*}{ Cultivation system } & \multirow{2}{*}{$\begin{array}{c}\text { FFB } 1 \text { for oil palm } \\
\left(\mathrm{kg}^{\mathrm{kg}} \text { bunches ha-1 } \mathrm{yr}^{-1}\right)\end{array}$} & \multicolumn{3}{|c|}{ Yield of intercrops per cultivation cycle ${ }^{2}$} \\
\hline & & Intercropped & Monoculture $^{4}$ & Unit \\
\hline Oil palm monoculture & $20,891.4$ & - & - & - \\
\hline Oil palm + Pineapple & $20,467.8$ & 11,732 & 32,589 & Fruits ha-1 \\
\hline Oil palm + Banana & $21,353.6$ & 7,980 & 21,568 & Kg bunches ha-1 \\
\hline Oil palm + Cassava & $21,177.2$ & 6,370 & 19,906 & Kg roots ha-1 \\
\hline Mean & $20,972.5$ & - & - & - \\
\hline
\end{tabular}


Tabela 4. Custo total do monocultivo do dendezeiro e dos sistemas de cultivos intercalares do dendezeiro com abacaxi, banana e mandioca durante os três primeiros anos após o plantio do dendezeiro, e percentual de participação dos principais componentes no custo total de produção.

Table 4. Total cost of oil palm monoculture and oil palm intercropping systems with pineapple, banana and cassava during the first three years after planting oil palm, and percentage of participation of major components in total production cost.

\begin{tabular}{|c|c|c|c|c|c|}
\hline \multirow{2}{*}{\multicolumn{2}{|c|}{ Production components }} & \multicolumn{4}{|c|}{ Cultivation System } \\
\hline & & Oil palm & Oil palm + Pineapple & Oil palm + Banana & Oil palm + Cassava \\
\hline \multirow[t]{2}{*}{ Total Cost $(\mathrm{R} \$)$} & & $7,016.28$ & $11,295.00$ & $12,729.45$ & $9,418.74$ \\
\hline & & \multicolumn{4}{|c|}{ Participation of each component $(\%)$ in total cost } \\
\hline \multirow{2}{*}{ Area preparation } & $\mathrm{Mc}^{1}$ & 17 & 11 & 10 & 13 \\
\hline & $\mathrm{Mn}^{2}$ & 5 & 5 & 6 & 5 \\
\hline \multirow{2}{*}{ Fert $^{5}$} & $\mathrm{Ch}^{3}$ & 25 & 33 & 29 & 25 \\
\hline & $\mathrm{Or}^{4}$ & - & - & 3 & - \\
\hline \multicolumn{2}{|l|}{ Pesticides } & - & 3 & - & - \\
\hline \multicolumn{2}{|c|}{ Equipments and tools } & 4 & 3 & 3 & 4 \\
\hline \multicolumn{2}{|l|}{ Post-implantation } & 37 & 29 & 29 & 36 \\
\hline \multicolumn{2}{|l|}{ Seedling } & 12 & 12 & 12 & 10 \\
\hline \multicolumn{2}{|l|}{ Harvest } & - & 4 & 8 & 7 \\
\hline
\end{tabular}

${ }^{1} \mathrm{Mc}-$ mecânico; ${ }^{2} \mathrm{Mn}$ - manual; ${ }^{3} \mathrm{Ch}-\mathrm{Chemical} ;{ }^{4} \mathrm{Or}$ - Organic; ${ }^{5}$ Fert. - Fertilizers. Productivity extrapolating average plot values to one hectare of monoculture with the same planting density as used during intercropping.

The second component with the largest cost share was fertilizer, ranging from 25 to $33 \%$ among the systems tested. And considering all the evaluated systems it was observed that the costs generated in the first year of cultivation ranged from 51 to $66 \%$ of the total costs per hectare.

In the oil palm monoculture system, total cost per hectare, including preparation/planting and maintenance in the unproductive phase, that is, until the third year after initiation, was $\mathrm{R} \$ 7,016.28$ (Figure 1A). In the oil palm + pineapple intercropping system, the total cost per hectare, considering system implementation and maintenance across three years was $\mathrm{R} \$ 11,295.47$ (Figure 1B). The pineapple crop cycle varied from 16 to 18 months, so it provided no revenue in the first year. In the second year the gross revenue of the system was $\mathrm{R} \$ 11,636.00$ per hectare, producing 6,766 first; 4,115 second and 750 third-class fruits, traded at $\mathrm{R} \$ 1.20, \mathrm{R} \$$ 0.80 and $R \$ 0.30$ per unit, respectively. Total revenue from pineapple crop, including amortizing $100 \%$ of system during implementation and maintenance costs, gave a net revenue of $\mathrm{R} \$ 340.53$ at the end of the three years.

For the oil palm + banana system, in the first year after planting there were only costs. The sale of banana in hands produced in the second and third year gave total gross revenues of $\mathrm{R} \$ 11,031.00 \mathrm{ha}^{-1}$, corresponding to $86.7 \%$ of system implementation and maintenance costs (Figure 1C).

For the oil palm + cassava crop, due to the cassava crop cycle being just eight months, there was revenue generation in the first year of cultivation, with $\mathrm{R} \$ 1,473.36$ generated from $6,146.00 \mathrm{~kg} \mathrm{ha}^{-1}$ of fresh roots. For all the three years, gross revenue of $\mathrm{R} \$ 6,079.26 \mathrm{ha}^{-1}$ was obtained (Figure 1D), this value covers $64.5 \%$ of the implantation and maintenance costs of the system.

Under the conditions of this study, in Manaus municipality, it was possible to amortize the system implementation costs with pineapple cultivation, reaching the equilibrium point in the 3rd year after planting. Thus, from the first year of oil palm harvest (the fourth year after planting), incurred costs would relate only to maintenance, with the producer already obtaining net income.

\section{DISCUSSION}

The annual average value of FFB observed in this study was similar to that estimated by Silva (2006) from commercial plantation FFB production in the state of Pará for cultivars Deli x La Mé (that includes the BRS C2501cultivar used here). However, Ramalho Filho et al. (2010) highlight that this cultivar has a productive potential of 25 to $30 \mathrm{t}$ of FFB $\mathrm{ha}^{-1}$ year ${ }^{-1}$, values that were not attained during the evaluation period. This lack of high production levels can be attributed to planting site pedoclimatic conditions, especially the soil, with had low fertility and a very clayey texture. In addition, according to equations for estimating yields of FFB given by Silva (2006), increases in productivity are still expected ten years after planting. Therefore, considering the planting age and the pedoclimatic conditions of the experimental area, an acceptable level of oil palm productivity was reached, one similar to those found in commercial plantations in the Amazon (Silva, 2006).

For intercrop cultivation, considering the edaphoclimatic conditions under which the experiment was conducted and the potential of the cultivars or species used, good overall yields were obtained. According to Gasparotto et al. (1999) the productive capacity of the Thap Maeo banana cultivar in Amazon Region low fertility soils may reach 25,000 kg hands $\mathrm{ha}^{-1}$. The cassava cultivar Aipim manteiga, harvested between 8 and 10 months after planting has producion potential of around 15,000 to $17,000 \mathrm{~kg}$ of roots ha-1 (Dias et al., 2003). For pineapple, as it is a regional variety grown by local producers, there are no yield estimates reported in the literature. However, according to the recommendations for pineapple cultivation in the Amazon (SILVA et al., 2004) it is possible get up to 42,000 fruits ha-1 ${ }^{-1}$ Averages yields achieved by intercrops and oil palm demonstrates the technical feasibility of these intercropping oil palm systems during the first three years after oil palm planting.

Most of the cultivation practices in the systems were performed manually, including part of the area preparation, planting, thinning, fertilization, control of spontaneous vegetation in the palm crown and inter-rows, as well as the harvesting. This is typical of the operational system of a small family farmer. In the study by Alves et al. (2015), which evaluated seven oil palm intercropping systems, including annual and semi-perrential plants, in different associations with cowpea, corn, peanut, cassava, banana and pineapple crops, the authors also identified for almost all systems the labor as main cost component. As in family agriculture 
manual labour is performed predominantly by the family, intercropping systems of oil palm cropping with annual or semi-perennial crops can provide an excellent alternative for income generation and amortization of oil palm implementation costs during three first years after planting, unproductive phase of oil palm cultivation.

A study in Pará by Muller; Furlan Júnior (2001) obtained similar results for the participation of labor in oil palm cultivation production costs. The authors noted that the costs of such agricultural operations as tillage, nursery, planting, mowing, pruning and fertilization, all of which are predominantly carried out manually by the family farmer, represent the largest percentage of total production costs. These ranged from $27 \%$ to $67 \%$ in practically all phases of the oil palm production cycle. The authors found fertilizers to be the second most important production cost. The total first year cultivation costs for the current study match those of Lopes et al. (2015), who observed values greater than 50\% in first year oil palm intercropping systems in Roraima, Brazil. Nchanji et al. (2016), in a study conducted in Cameroon, noted that acquisition of seeds and seedlings represented

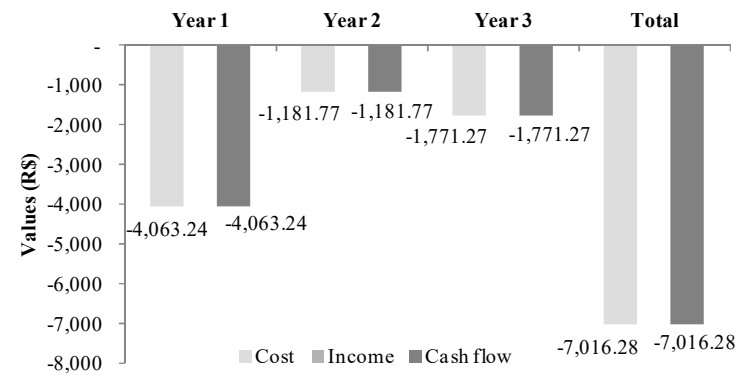

(A)

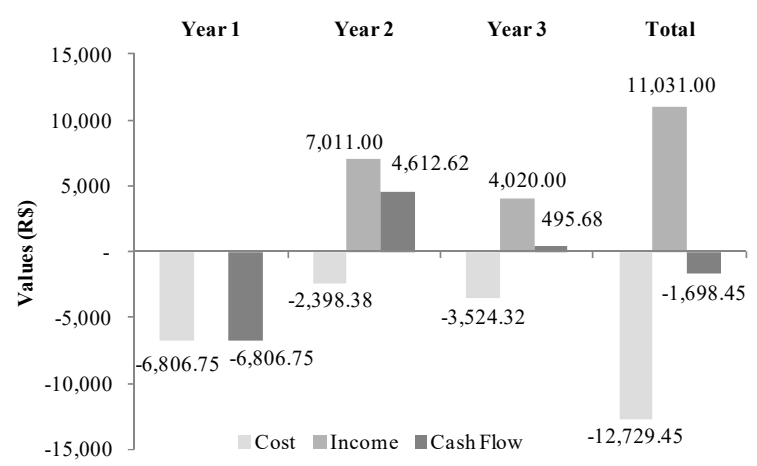

(C)
$34 \%$ of the costs in the implementation and maintenance phase of different food crops intercropped with oil palm. However, these authors did not include in the analysis the costs related to labor, which according to San Cortés (2003) is predominantly family-based in small production units in Cameroon.

For oil palm monoculture system the total cost per hectare was similar to the costs reported by Lopes et al. (2015) in Roraima, $\mathrm{R} \$ 8,086.56$, and somewhat higher than the total cost per hectare in the state of Pará, $\mathrm{R} \$ 4,746.00$ (AGRIANUAL, 2011).

For an oil palm monoculture in Pará, Muller and Furlan Júnior (2001) reported that the equilibrium point of the agricultural component was reaching at the 9th year after oil palm planting. Anticipating the break-even point of agricultural component of oil palm plantation due to income from intercrops can substantially contribute to increasing viability of oil palm cultivation by family-based farming. The choice of the species to be cultivated in intercropping with oil palm will depend on the analysis of the demand and value paid for products in the local market.

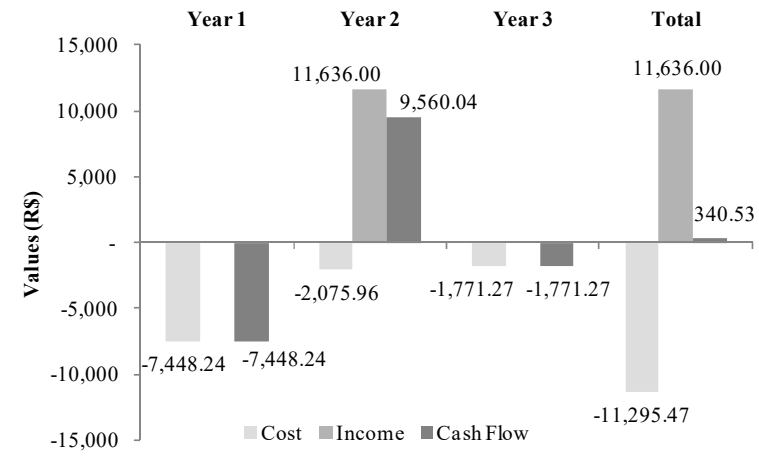

(B)

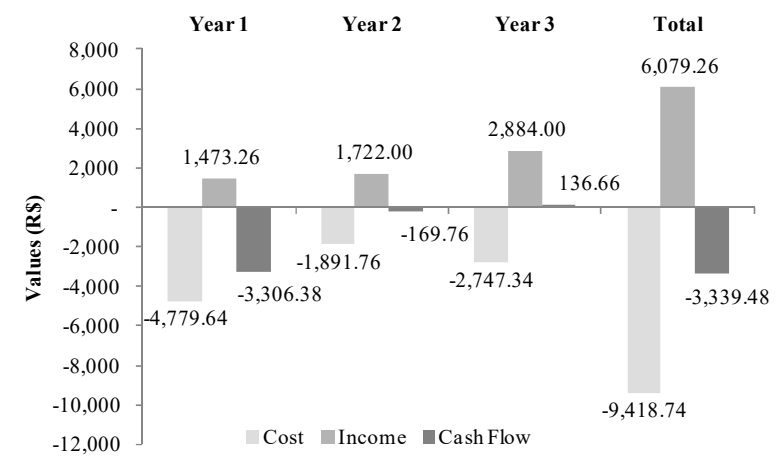

(D)

Figura 1. Custo, receita e fluxo de caixa do dendezeiro em monocultivo (A) e com o cultivo intercalar de abacaxi (B), banana (C) e mandioca (D) durante três anos pós-plantio do dendezeiro.

Figure 1. Cost, income and cash flow for oil palm monoculture (A) and intercropping with pineapple (B), banana (C) and cassava (D) for three years after planting oil palm.

The use of cash flow to compare oil palm intercropping systems allows the producer to choose those systems giving the highest net nominal revenue (PADOVEZE, 2011). However, if poorly planned, this can lead to erroneous decisions jeopardizing the producer's investments (HANSEN; MOWEN, 2013).

The possibility of generating income in the unproductive phase of oil palm cultivation, as is possible via intercropping systems, provides a means of circumventing one of the main constraints of family-based oil palm cultivation, the generation revenue to pay for the implementation and maintenance costs of the crop in the unproductive phase and also to support the producers until the sale of oil palm bunches production begins. Nchanji et al. (2016) also point out that the use of intercropping in the young phase of oil palm plantations helps not only to amortize the costs of planting the crop, but also to maximize the use of the area with income generation, reducing the need for small producers to deforest land in order to plant food crops during the unproductive oil palm period. Thus, the proposed 
systems has the potential to provide agricultural, social, economic and environmental benefits.

\section{CONCLUSÕES}

Cultivation of pineapple, banana and cassava intercropped between the oil palm rows, in the initial three years, does not affect the oil palm productivity when the appropriate cultivation recommendations are adopted.

The yield of the crops: pineapple, banana and cassava, grown between rows of oil palm in the three years after planting is similar to that obtained from monocultures of these crops.

The cultivation of pineapple, banana and cassava between oil palm rows, during the three years after planting, is a technically and economically viable alternative for income generation and amortization of oil palm implementation and maintenance costs during its non-productive initial phase.

\section{REFERÊNCIAS}

ABERA, T.; FEYISA, D. Faba bean and field pea seed proportion for intercropping system in Horro Highlands of Western Ethiopia. African Crop Science Journal, Kampala, v. 16, n. 4, p. 243-249, 2009. DOI: https://dx.doi.org/10.4314/acsj.v16i4.54398

AGRIANUAL. Anuário da Agricultura Brasileira. São Paulo: FNP Consultoria Andamp, 2011. 482 p.

ALVES, A. B.; CORDEIRO, A. C. C.; CHAGAS, E. A.; LOPES, A. D. O.; VAZANO, R. M. B.; LUCAS, J. G. S. Cultivos Intercalares com Palma de Óleo (Dendê) em Roraima. Boa Vista: Embrapa Roraima. 2015. 57 p.

AYNEHBAND, A.; BEHROOZ, M.; AFSHAR, A. H. Study of intercropping agroecosystem productivity influenced by different crops and planting rations. American-Eurasian Journal of Agricultural \& Environmental Sciences, v. 7, n. 2, p. 163-169, 2010.

CORLEY, R. H. V. How much palm oil do we need? Environmental Science \& Policy, Carouge, v. 12, n. 2, p. 134-139, abr. 2009. DOI: https://dx.doi.org/10.1016/j.envsci.2008.10.011

DIAS, M. C.; XAVIER, J. J. B. N.; BARRETO, J. F.; FUKUDA, W. M. G. Aipim Manteiga: Cultivar de macaxeira para o Amazonas. Manaus: Embrapa Amazônia Ocidental, 2003. 4 p.

GASPAROTTO, L.; COELHO, A. F. S.; PEREIRA, M. C. N.; PEREIRA, J. C. R.; CORDEIRO, Z. J. M.; SILVA, S. O. Thap maeo e Caipira: Cultivares de bananeira resistentes à sigatoka negra, para o estado do Amazonas. Manaus: Embrapa Amazônia Ocidental, 1999. 5 p.

GASPAROTTO, L.; PEREIRA, J.C.R. A cultura da bananeira na região Norte do Brasil. Brasília: Embrapa Informação Tecnológica, 2010. 310 p.

HANSEN, D. R.; MOWEN, M. M. Gestão de custos: contabilidade e controle. 3. ed. São Paulo: Pioneira Thomson Learning: Cengage Learning, 783 p. 2013.

ISMAIL, S.; KHASIM, N.; OMAR, R. Z. R. Double-row avenue system for crop integration with oil palm. MPOB Information Series, v. 465, n. 424, p. 1-4, jun. 2009.

MULLER, A. A.; FURLAN JUNIOR, J. Agronegócio do dendê: uma alternativa social, econômica e ambiental para o desenvolvimento sustentável da Amazônia, Belém: Embrapa Amazônia Oriental, 2001. $288 \mathrm{p}$.
LIMA, S. M. V.; FREITAS FILHO, A.; CASTRO, A. M. G.; SOUZA, H.R. Desempenho da cadeia produtiva do dendê na Amazônia Legal. Brasília: SUDAM/FADE, 2002. $150 \mathrm{p}$.

LOPES, A. D. O.; CORDEIRO, A. C. C.; CHAGAS, E. A.; LOZANO, R. M. B.; ALVES, A. B. MACIEL, F. C. S. Viabilidade técnica e avaliação financeira de cultivos intercalares no desenvolvimento inicial da palma-de-óleo em Roraima. Revista de Ciências Agrárias, Belém, v. 58, n. 4, p. 442-450, out./dez. 2015.

NCHANJI, Y. K.; NKONGHO, R. N.; MALA, W. A.; LEVANG, P. Efficacy of oil palm intercropping by smallholders. Case study in South-West Cameroon. Agroforest System, v. 90, n. 3, p. 509-519, jun. 2016. DOI: https://dx.doi.org/10.1007/s10457-015-9873-z

RAMALHO FILHO, A.; MOTTA, P. E. F.; FREITAS, P. L.; TEIXEIRA, W. G. Zoneamento agroecológico, produção e manejo para a cultura da dendezeiro na Amazônia. Rio de Janeiro: Embrapa Solos, 2010. 216 p. REZIG, M.; SAHLI, A.; JEDDI, F. B.; HARBAOUI, Y. Adopting intercropping system for potatoes as practice on drought mitigation under Tunisian conditions. Options Mediterraneennes, v. 95, p. 329-334. 2010.

PADOVEZE, C.L. Introdução à Administração Financeira. 2. ed. São Paulo-SP: Cengage Learning, 2011. v. 1. 303 p.

SAN CORTÉS, R. Terminology used in "family agriculture systems" research. CIRAD-TERA, v. 49, 20 p. 2003.

SANTANA, E.C. Elementos de economia, agronegócio e desenvolvimento local. Belém: GTZ; TUD; UFRA, 2005.

SANTOS, H. G. dos; JACOMINE, P. K. T., ANJOS, L. H. C. dos; OLIVEIRA, V. A. de; LUMBRERAS, J. F.; COELHO, M. R.; ALMEIDA, J. A. de; CUNHA, T. J. F.; OLIVEIRA, J. B. de. Sistema Brasileiro de Classificação de Solos. 3 ed. rev. ampl. Brasília: EMBRAPA, 2013.

SILVA, J. S. O. Produtividade de óleo de palma na cultura do dendê na Amazônia Oriental: influência do clima e do material genético. 2006. 65f. Dissertação (Mestrado em Fitotecnia), Universidade Federal de Viçosa, Viçosa, 2006.

SILVA, S. E. L.; SOUZA, A. G. C.; BERNI, R. F.; SOUZA, M. G. A Cultura do Abacaxizeiro no Amazonas. Manaus: Embrapa Amazônia Ocidental. 2004. 6 p.

SOUZA, M. B.; RODRIGUES, M. R. L.; ROCHA, R. N. C.; CRAVO, M. S.; CORDEIRO, A. C. C.; BOARI, A. J.; MENEZES, A. J. E. A.; ARAGÃO, D. V.; SILVA, E. S. A.; SANTOS, J. C.; MAUÉS, M. M.; OLIVEIRA, M. E. C.; MODESTO JÚNIOR, M. S.; ALVES, R. N. B.; FRANZINI, V. I.; GOMES JÚNIOR, R. A. Cultivo intercalar de culturas alimentares com palma de óleo na fase pré-produtiva. Belém: Embrapa Amazônia Oriental, 2016. 31 p.

USDA_UNITED STATES DEPARTAMENT OF AGRICULTURE. World Supply and Use of Oilseeds and Oilseed Products. 2017. Disponível em: <https://www.ers.usda.gov/webdocs/DataFiles/52218 /AllYearbook $\% 20$ tables.pdf?v $=0>$. Acesso em: 03 mar. 2018.

VIÉGAS, I. J.; MÜLLER, A. A. A cultura do dendezeiro na Amazônia brasileira. Belém: Embrapa Amazônia Oriental/Manaus: Embrapa Amazônia Ocidental, 2000. 374 p. 